\title{
PROFIL LABORATORIUM IPA/BIOLOGI DAN KOMPETENSI GURU PENGELOLA LABORATORIUM SMA SWASTA DI KOTA PEKANBARU
}

\author{
(Profile of Science / Biology Laboratory and Competency of Private High \\ School Laboratory Management Teachers in the city of Pekanbaru)
}

\author{
Oleh: Laili Rahmi *)
}

*) Dosen Biologi FKIP UIR

\begin{abstract}
The study was conducted with the aim of wanting to find out the biology laboratory profiles in high schools, especially private. Research was carried out on private high schools in the city of Pekanbaru T.A 2016/2017, as the research sample was carried out in a random way. This research method was using surveys, documentation and observation. The research instrument used in this study was documentation guidelines for knowing the Biology Science lab in high school. The results of the data analyzed descriptively regarding the Profile of the Biological Science Laboratory of SMAS in Pekanbaru showed that the Biology Science laboratory conditions were undergraduate and S4 in $89.4 \%$ (Very good), and each indicator observed at the time of observation showed good laboratory conditions.
\end{abstract}

Keywords: Profile, Biology Science Laboratory, Private Middle School (SMAS)

\section{PENDAHULUAN}

Laboratorium adalah suatu ruangan tempat melakukan kegiatan praktek atau penelitian yang ditunjang oleh adanya seperangkat alat-alat laboratorium serta adanya infrastruktur laboratorium yang lengkap, (Widyarti (2005: 1). Pentingnya laboratorium dalam menunjang pembelajaran di kelas sangat diyakini oleh semua guru IPA. Dalam perkembangannya, kata "laboratorium" mempertahankan arti aslinya, yaitu "tempat bekerja", tetapi khusus untuk keperluan penelitian ilmiah di sekolah, agar laboratorium dapat berfungsi sesuai dengan maksud pengadaannya, laboratorium perlu digunakan dan dikelola dengan sebaik-baiknya. Tanpa digunakan dan dikelola dengan baik pengadaan laboratorium beserta alat-alat dan bahan yang diperlukan hanyalah akan merupakan suatu penerobosan (Kertiasa, 2006).

Permendiknas No.27 Tahun 2007 menjelaskan bahwa tingkat keefektifan dalam pemanfaatan laboratorium sangat berdampak terhadap keberhasilan pembelajaran dan keefektifan penggunaan laboratorium dalam penelitian ini ditentukan oleh sejauh mana ketercapaiankelengkapan sarana prasarana laboratorium menurut standar pendidikan kemampuan guru dalammenggunakan laboratorium, serta teknis pengelolaan laboratorium.

Hal senada dinyatakan oleh Suyanta (2010: 1), bahwa pengelolaan laboratorium akan berjalan dengan lebih efektif bilamana dalam struktur organisasi laboratorium didukung oleh Board of Management yang berfungsi sebagai pengarah dan penasehat. Board of Management terdiri atas para senior/professor yang mempunyai kompetensi dengan kegiatan laboratorium yang bersangkutan.

Seperti yang dilakukan oleh Sundoro, dkk (2013) bahwa sarana dan prasarana yang standar di laboratorium merupakan hal yang penting, mengingat ada hubungan used factor alat dengan hasil belajar, faktor ruangan laboratorium yang sesuai 
dengan hakikat pembelajaran sains dan potensi guru dalam mengoptimalkan penggunaan laboratorium. Selanjutnya hal serupa dikemukakanan oleh Tessier (2010), yang menyatakan penggunaan penyelidikan berbasis laboratorium di program pendidikan guru yang nantinya di terapkan di kelas akan mendorong guru untuk menggunkan penyelidikan dalam pembelajaran kepada siswa.

Kegiatan praktikum IPA di SMA belum begitu optimal, para siswa lebih banyak menerima materi teori seputar konsep dibanding melakukan percobaan yang sesuai konten materi yang seharusnya dilakukan percobaan di laboratorium. Tidak seluruh SMA Swasta di kota Pekanbaru memiliki laboratorium IPA. Selama ini masih belum banyak publikasi ilmiah mengenai gambaran laboratorium, yang dilaksanakan disekolahsekolah SMA khususnya di kota Pekanbaru.

\section{METODE PENELITIAN}

Jenis penelitian ini merupakan penelitian kuantitatif deskriptif yang akan memaparkan data dari Profil Laboratorium IPA/Biologi SMA Swasta (SMAS) di Kota Pekanbaru.

\section{A. Tempat dan Waktu Penelitian}

Penelitia ini dilaksanakan pada SMA Swasta di Kota Pekanbaru T.A 2016/2017, penelitian dan pengabilan data awaldilakukanpadabuln April 2017 kemudiandilanjutkan penelitianpada bulan Juni 2017 sampai dengan Maret 2018.

\section{B. Populasi dan Sampel \\ 1. Populasi}

Populasi menurut Sugiyono (2013:117) adalah wilayah generalisasi yang terdiri atas: objek/subjek yang memiliki kualitas dan karakteristik khusus yang ditetapkan peneliti, untuk diamati, dipelajari dan kemudian ditarik kesimpulannya. Populasi dalam penelitian ini terdiri dari sebelas kecamatan yang ada di kota Pekanbaru.

\section{Sampel}

Sampel menurut Sugiyono (2009:81) adalah bagian dari jumlah dan karakteristik yang dimiliki oleh populasi tertentu. Pada penelitian ini populasi yang diambil sebagai sampel penelitian dilakukan dengan teknik sampling menggunakan random sampling pada kategori sekolah SMA Swasta (SMAS) di Pekanbaru.

\section{Teknik Pengumpulan Data dan Istrumen Penelitian}

Teknik yang digunakan pada penelitian ini dalam pengumpulan data yaitu dengan melakukan survei melalui teknik observasi, studi dokumentasi dan wawancara. Instrumen penelitian yang digunakan dalam penelitian ini adalah pedoman dokumentasi, dan pedoman wawancara untuk mengetahui kondisidanprofil laboratorium IPA Biologi

\section{Teknik Analisis Data}

Data mengenai profil laboratorium di jaring dengan menggunakan lembar pengamatan/observasi yang mengacu pada Permendiknas nomor 24 tahun 2007 tentang Standar Sarana Prasarana Laboratorium IPA SMA. Selanjutnya data di analisis dengan menggunkan teknik presentasi dianalisis menggunakan rumus sebagai berikut:

$P=f / N \times 100 \%$

(Sudijono, 2010)

Keterangan:

$\mathrm{P}$ : Persentase

f :Jumlah subyek yang ada pada kategori tertentu (data rill)

$\mathrm{N}$ : Frekuensi total atau keseluruhan jumlah subyek (data rasio)

Berdasarkan hasil

perhitungan skor lembar observasi merujuk pada kriteria pada tabel 1 . sebagai berikut : 
Tabel. Pedoman Interval Pengamatan

\begin{tabular}{cc}
\hline Interval & Keterangan \\
\hline $0 \%-20 \%$ & $\begin{array}{c}\text { SangatKurang } \\
\text { Standar }\end{array}$ \\
\hline $21 \%-40 \%$ & Kurang Standar \\
\hline $41 \%-60 \%$ & Cukup Standar \\
\hline $61 \%-80 \%$ & Standar \\
\hline $81 \%-100 \%$ & Sangat Standar \\
\hline
\end{tabular}

Sumber: Modifikasi dari Arikunto, 2013

\section{HASIL DAN PEMBAHASAN}

\section{A. Deskripsi Umum Lokasi danSubjekPenelitian}

Penelitai ini merupakan jenis penelitian deskriptif kuantitatif dimana objek yang diteliti dan diamati pada penelitian ini adalah Profil laboratorium IPA Biologi di beberapa sekolah SMA Swasta (SMAS) yang ada di Pekanbaru, sebagai Sample Penelitian terdiri dari 7 SMAS yang ada diwilayahkabupatenkota Pekanbaru.

Subjek penelitian yang berkaitan dengan sekolah SMAS dalam penelitia ini adalah sekolah yang bersedia dijadikan sebagai lokasi penelitian Profil Laboratorium IPA Biologi. Selain itu sampel ditentuk dengan acak (random sampling).Data yang diperoleh berasal dari data observasi, wawancar dan dokumentasi.

\section{HASIL PENELITIAN DAN PEMBAHASAN}

Penelitai ini merupakan jenis penelitian deskriptif kuantitatif dimana objek yang diteliti dan diamati pada penelitian ini adalah Profil laboratorium IPA Biologi di beberapa sekolah SMA Swasta (SMAS) yang ada di Pekanbaru, sebagai Sample Penelitian terdiri dari 7 SMAS yang ada diwilayahkabupatenkota Pekanbaru.

Subjek penelitian yang berkaitan dengan sekolah SMAS dalam penelitia ini adalah sekolah yang bersedia dijadikan sebagai lokasi penelitian Profil Laboratorium IPA Biologi. Selain itu sampel ditentuk dengan acak (random sampling).Data yang diperoleh berasal dari data observasi, wawancar dan dokumentasi.

\section{Analisis Data Profil Laboratorium IPA Biologi SMAS Pekanbaru}

Data yang dianalisis secara deskriptif adalah data Profil Laboratorium IPA Biologi SMAS yang ada di Pekanbaru dengan menggunakan Lembar Observasi dengan cara ceklis kemudian hasil data ini dideskripsikan presentasikan dan mencatata kondisi laboratorium serta dokumentasi yang merujuk pada Permendiknas No. 24 Tahun 2007 tentang standar Laboratorium Sekolah, berdasarkan data penelitian dari 7 sekolah SMAS di Pekanbaru, maka dapat dilihat pada Tabel 1, sebagai berikut:

\section{Tabel 1. Profil Laboratorium IPA Biologi SMAS Pekanbaru}

\begin{tabular}{|c|c|c|c|c|c|c|c|c|c|}
\hline \multirow[t]{2}{*}{ No } & \multirow{2}{*}{$\begin{array}{l}\text { Laboratorium } \\
\text { Sekolah (S-N) }\end{array}$} & \multicolumn{5}{|c|}{ Indikator yang diamati (\%) } & \multirow[t]{2}{*}{ Skor } & \multirow{2}{*}{$\begin{array}{l}\text { ersentasi } \\
(\%)\end{array}$} & \multirow[t]{2}{*}{ Kategor } \\
\hline & & 1 & 2 & 3 & 4 & 5 & & & \\
\hline 1. & S-1 & 100 & 75 & 100 & 84 & 88 & 447 & $89,4 \%$ & $\begin{array}{l}\text { Sangat } \\
\text { Standar }\end{array}$ \\
\hline 2. & S-2 & 71 & 60 & 100 & 53 & 91 & 375 & $75 \%$ & Standar \\
\hline 3. & S-3 & 57 & 58 & 100 & 8 & 44 & 267 & $53,4 \%$ & $\begin{array}{l}\text { Cukup } \\
\text { Standar }\end{array}$ \\
\hline 4. & S-4 & 100 & 75 & 100 & 72 & 100 & 447 & $89,4 \%$ & $\begin{array}{l}\text { Sangat } \\
\text { Standar }\end{array}$ \\
\hline 5. & S-5 & 63 & 54 & 100 & 42 & 87 & 259 & $51,83 \%$ & $\begin{array}{l}\text { Cukup } \\
\text { Standar }\end{array}$ \\
\hline 6. & S-6 & 54 & 48 & 100 & 18 & 94 & 314 & $62,8 \%$ & Standar \\
\hline 7. & S-7 & 72 & 65 & 100 & 23 & 98 & 358 & $71,6 \%$ & Standar \\
\hline & Persentase & 75.85 & 62.14 & 100 & 42.85 & 86.00 & & & \\
\hline
\end{tabular}


Keterangan:

1. Perabot

2. Peralatan pendidikan

3. Media pendidikan

4. Bahan habis pakai

5. Perlengkapan lain

Berdasarkan indikator 1. Perabot dengan persentase $75.85 \%$, menunjukkan profil pada tujuhsekolah berada pada kategori standar dan sesuai dengan standar Permendiknas No. 24 Tahun 2007 tentang Sarana dan Prasarana Laborotorium yang diamati pada Laboratorium IPA Biologi. Indikator 2. Peralatan pendidikan di laborratorium IPA Biologi dengan persentase $62.14 \%$, menunjukkan profil pada tujuh sekolah berada pada kategori baik. Namun untuksekolah S-3, S-5, dan S-6 sebagian peralatan pendidikan yang menunjang pembelajaran masih belum standar dan belum lengkap, dari data observasi juga menujukkan pemeliharan alat pendidikan dilaboratorium di beberapa sekolah belum dikelola dengan baik. Indikator 3. Media pendidikan di laboratorium di IPA Biologi pada tujuh sekolah berada pada kategori $100 \%$ sangat baik, berdasarkan observasi pada saat penelitian menunjukkan media pendidikan seperti papan tulis disediakan pada semua laboratorium IPA Biologi. Serta penggunaan papan tulis menjadi bagian yang amat membantu guru dalam menjelaskan dan memandu praktikum di laboratorium. Indikator 4. Bahanhabis pakai dari tujuh laboratorium sekolah berada pada kategori $42.85 \%$ cukup baik. Berdasarkan observasi pada saat penelitian, bahan habis pakai dilaboratorium belum sesuai dengan standar Permendiknas. Sebagian bahan habis pakai tidak disediakan, pemakaian bahan habis pakai juga tidak terkoordinasi dengan baik, misalnya bahan habis pakai yang sudah kadaluarsa masih disimpan di lemari dan bahkan masih dipakai pada saat praktium.

Perlengkapan lain yang ada di laboratorium pada indikator 5 menjelaskan untuk tujuh sekolah berada pada kategori
$86.00 \%$ sangat baik. Peralatan lain seperti tong sampah, jam diding dan lainnya sudah disediakan di ruangan laboratorium. Berdasarkan standar Permendiknas peralatan tersebut perlu bagi praktikan atau siswa yang sedang melakukan praktikum, agar ruangan laboratorium bisa menjaga kebersihan, siswa juga tau berapa lama pelaksanaan praktikum di laboratorium.

Tabel 1. menunjukkan kondisi laboratorium IPA Biologi disekolah S1 dan S-4 dalam prersentasi 89,4 \% (Sangat baik), selain itu setiap indikator yang diamati pada saat observasi menunjukkan skor yang baik. Hal ini diamati pada saat observasi keberaan sarana dan prasarana laboratorium IPA Biologi yang ada pada kedua sekolah tersebut memang terkooradinasi dan sangat terawat, bahkan untuk sekolah S-1 pengelola laboratorium IPA di sekolah telah memiliki tenaga laboran khusus yang bertanggung jawab dalam semua aktivitas belajar di laboratorium Biologi. Standar Laboratorium IPA Biologi yang ada di sekolah S1 dan S-4 sesuai dengan tuntunan pada Permendiknas No.24 Tahun 2007, dan dalam kondisi yang sangat baik dan terawat.

Sedangkan pada sekolah S-3 dan S-5 menunjukkan kondisi laboraturium IPA Biologi pada kondisi yang Cukup Baik, hal ini dikarenakan tidak semua indikator yang diamati pada saat observasi menunjukkan hasil yang baik. Pada saat observasi hasil pengamatan di laboratorium sekolah S3 adalah 53,4 \% dan S-5 51,83\%. 
Keadaan ini di karenakan koordinasi dan perawatan laboratorium beserta peralatan yang ada masih kurang di perhatikan. Serta mengenai pengelolaan laboratorium masih belum spesifik di kelola oleh tenaga laboran, seperti kepala sekolah yang bertanggung jawab dalam mengakomodir laboratorium. Guru mata pelajaran IPA yang belum mendapatkan pelatihan pengelolaan laboratorium. Selain itu keterangan lainnnya menunjukkan guru yang bertugas dalam pengelolaan Laboratorium Biologi juga masih baru diangkat menjadi pengelola laboratorium. Hal tersebut menjadikan penjelasan mengenai mengapa sarana dan prasarana serta pengelolaan di Labororium khususnya Biologi pada kategori cukup baik di sekolah S-3 dan S-5 tersebut.

Berdasarkan hasil perhitungan pada setiap indikator pengamatan mengenai kondisi Laboratorium IPA Biologi menunjukkan hasil skor pengamatan yang dapat dilihat pada gambar 1 , berikut ini;

\section{Analisis Data Kompetensi Guru Pengelola Laboratorium}

Data mengenai kompetensi guru pengelola laboratorium di skolah SMAS Pekanbaru dianalisis secara deskriptif yang berasal dari angket dan wawancara kepada subjek yang diamati, dalam hal ini adalah guru pengelola Laboratorium IPA Biologi. Angket yang dijadikan sebagai instrumen penelitian ini merujuk pada Permendiknas No.26 Tahun 2008 tentang Standar Tenaga Pengelola Laboratorium Sekolah/Madrasah. Berdasarkan data yang diperoleh dari 7 guru dari 7 sekolah yang juga diambil data mengenai Laboratorium sekolah, maka data dapat dilihat pada Tabel 2, sebagai berikut:

Tabel 2.Data Kompetensi Guru Pengelola Laboratorium

\begin{tabular}{|c|c|c|c|c|c|c|c|c|c|}
\hline \multirow[t]{2}{*}{ No } & \multirow{2}{*}{$\begin{array}{c}\text { Laboran } \\
\text { Sekolah/S) }\end{array}$} & \multicolumn{5}{|c|}{$\begin{array}{c}\text { Kompetensi Guru Pengelola } \\
\text { Laboratorium IPA Biologi }(\%)\end{array}$} & \multirow[t]{2}{*}{ Skor } & \multirow{2}{*}{$\begin{array}{c}\text { Persentase } \\
(\%)\end{array}$} & \multirow[t]{2}{*}{ Kategori } \\
\hline & & 1 & 2 & 3 & 4 & 5 & & & \\
\hline 1. & S1 & 100 & 88 & 87 & 77 & 73 & 425 & $85 \%$ & Sangat Kompeten \\
\hline 2. & $\mathrm{~S} 2$ & 100 & 85 & 100 & 77 & 75 & 435 & $87,4 \%$ & Sangat Kompeten \\
\hline 3. & S3 & 100 & 76 & 76 & 70 & 87 & 409 & $81,8 \%$ & Kompeten \\
\hline 4. & S4 & 91,7 & 100 & 100 & 39 & 77 & 407 & $81,54 \%$ & Kompeten \\
\hline 5. & S5 & 94 & 85 & 85 & 57 & 87 & 408 & $81,6 \%$ & Kompeten \\
\hline 6. & S6 & 88 & 76 & 91 & 60 & 77 & 392 & $78,4 \%$ & Kompeten \\
\hline 7. & S7 & 96,3 & 77 & 78 & 77 & 82 & 410 & $82,06 \%$ & Kompeten \\
\hline \multicolumn{2}{|c|}{ Persentase } & 95.71 & 83.85 & 88.14 & 65.28 & 79.71 & & & \\
\hline
\end{tabular}

Keterangan:

1. Kompetensi Kualifikasi

2. KompetensiKepribadian

3. Kompetenasi Sosial

4. KompetensiManjerial

5. KompetensiProfesional

Berdasarkan indikator 1. Kompetensi Kualifikasi adalah $95.71 \%$, kompetensi dari tujuh guru pengelola laboratorium berada pada kategori sangat kompeten dan sesuai dengan standar Permendiknas No. 26 Tahun 2008. Observasi menunjukkan guru pengelola di sekolah S1, S2 dan S3 sudah memiliki sertifikat laboran dan sudah mengikuti pelatihan teknik pengelolaan laboratoriu, serta memiliki pengalaman mengelola laboratorium IPA lebih dari 3 tahun.

Indikator 2. Kompetensi kepribadian dari tujuh guru yang diteliti berada pada katergori $83.85 \%$ kompeten. Pada indikator kepribadian guru dalam mengelola laboratorium sudah menunjukkan komitmensi terhadap tugas yang diamanah dari sekolah. Indikator 3. Kompetensi sosial untuk tujuh guru yang diteliti berada pada kategori $88.14 \%$ 
sangat kompeten. Pada kompetensi ini guru memiliki kerjasama yang sangat baik dalam menjalakan fungsi laboratorium, guru pengelola laboratorium menginformasikan hal-hal yang berkaitan dengan laboratorium kepada guru bidang studi IPA, guna kepentingan pembelajaran. Kompetensi manjerial pada indikator 4. Menunjukkkan kategori $65.28 \%$ cukup kompeten. Hal ini dianggap masih perlu diperhatian dan pelatiahan dari pemerintah maupun dinas terakait untuk membantu para guru pengelola laboratorium dalam mengelola laboratorium sekolah, misalnya dalam merancang pengembangan laboratorium, memantau sarana dan prasarana laboratorium, mengevaluasi kinerja di laboratorium dan juga memantau kegiatan pembelajaran dilaboratorium. Kompetensi Profesional pada indikator 5. Menunjukkan kategori $79.71 \%$ kompeten. Tujuh guru yang diambil responnya menujukkan kompetensi yang baik. Guru pengelola laboratorium sudah menguasai prinsip-prinsip dasar laboratorium dalam mengelola laboratorium. Serta telah mendapatkan teori mengenai keselamatan dan kesehatan kerja dilaboratorium. Hal ini penting bagi guru pengelola laboratorium dalam menjalankan laboratorium yang aman dan nyaman bagi keperluan pembelajaran dan penelitian disekolah.

Data dari penelitian menunjukkan dua guru yang diambil data angketnya dari sekolah S-1 nilai kompetensi $85 \%$ (sangat kompeten), dan S-2 nilai kompetensi $87,4 \%$ (sangat kompeten). Guru pada sekolah S-3, S-4, S-5, S-6, dan S-7 mendapatkan nilai pada kategori kompeten. kompetensi guru pengelola laboratorium diketahui bahwa semua guru yang dijadikan sampel penelitian sebagian sudah pernah mendapatkan pelatihan mengenai teknik pengelolaan laboratorium IPA, dan memiliki sertifikat pengelola laboratorium IPA. Selain itu mengelola laboratorium sekolah tersebut sudah mengelola laboratorium lebih dari 3 tahun, laboran di sekoalah tersebut dan juga mendapakan pelatihan dan memiliki sertifikat laboran. Hal inilah yang memjadikan beliau memiliki pengalaman yang baik dalam pengelolaan laboratorium yang ada di sekolah S-1 tersebut. Pengalaman menjadi pengelola laboratorium juga menjadi halyang penting bagi tenaga laboran serta guru pengelola laboratorium dalam menjalankan aktivitas di laboratorium, sehingga pengalama belajar lebih bermakna.

Data penelitian mengenai kompetensi guru pengelola laboratorium dari 7 sekolah SMAS yang ada di Pekanbaru dapat dilihat pada gambar 1, berikut ini:

\section{Gambar 1. Hasil data Kompetensi Guru Pengelola Laboratorium IPA Biologi SMAS di Pekanbaru}

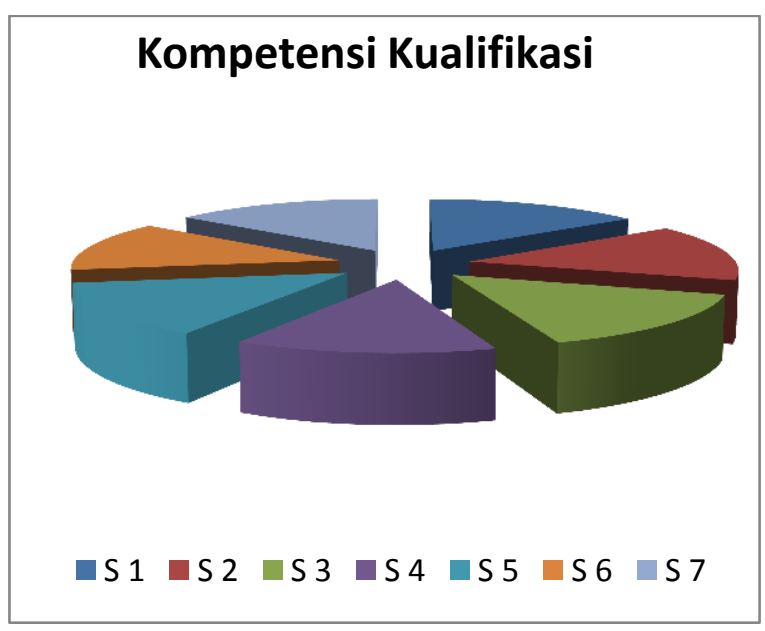

Berdasarkan gambar diatas, kompetensi pengelolaan laboratorium IPA Biologi SMAS pada tujuh guru pengelola yang di ambil data penelitian menunjukkan kompetensi yang baik dan kompeten, dari data yang di amati kompoetensi guru pengelola laboratorium IPA Biologi SMAS Pekanbaru sesuai dengan tuntunan Permendiknas No. 26 tahun 2008. Sedangkan profil laboratorium biologi dari tujuh sekolah yang diamati menunjukkan kondisi 
laboratorium yang baik dan sebagian laboratorium dalam kondisi sangat terawat.

\section{DAFTAR PUSTAKA}

Arikunto, S. (2013) Manajemen Penelitian, RinekaCipta, Jakarta.

Elseria.2016.Efektivitas Pengelolaan Laboratorium IPA.Vol.10. Diakses 15 Oktober 2017.

Mastika, N., Adnyana,P.,danSetiawan, G.2014.

AnalisisStandarisasiLaboratoriumBio logidalam Proses Pembelajaran di SMA Negerikota Denpasar. UniversitasPendidikanGanesha :Singaraja.

http://pasca.undiksha.ac.id.Vol. 4.Diakses20 September 2017

Peraturan Pemerintah Nomor 19 Tahun 2005.Standar Nasional Pendidikan.Jakarta

Permendiknas Nomor 24 Tahun 2007.Standar Sarana dan PrasaranaSekolah. Jakarta

Riduwan, Sunarto. Pengantar Stastika.2015. Bandung:Alfabeta

Sanjaya,

Wina.2014. PenelitianPendidikanJenis, Metode, danProsedur. Jakarta: Kencana

Sugiyono. 2009. Metode Penelitian Administratif. Raja Grafindo Persada. Jakarta

Suryani,Hendryadi.2015.Metode Riset Kuantitatif:Prenadamedia.Jakarta

UU RI. 2003.SistemPendidikan Nasional.Jakarta 
